\title{
Making and keeping agreements in medieval Catalonia, 1000-1200
}

\author{
Adam Joshua Kosto \\ The Deparment of History \\ Washington State University. USA
}

\section{Abstract}

The author proposes an explanation of the diplomatic, judicial and political context in which the convenientia emerged - a documentary typology which establishes an individual and private agreement in Catalonia during the 11 th and 12 th centuries, concerning a wide variety of legal acts - tracing a description of the development of its political and social employment as an important element of structure. He also indicates the causes of its further decline.

Key words: castle holding, episcopal and monastic military lordship, comital power, convenientia, agreement, Catalonia.

Resum. Fer i observar acords a la Catalunya altomedieval (1000-1200)

L'autor proposa una explicació del context diplomàtic, jurídic i polític de l'aparició de la convenientia - una tipologia documental que estableix un contracte individual i privat al voltant d'una àmplia diversitat d'actes juridics, a la Catalunya dels segles XI i XII. Estudia el desenvolupament del seu ús social i polític com un element important d'estructura $i$ assenyala les causes de la seva decadència.

Paraules clau: tinença de castells, domini militar episcopal i monàstic, poder comtal, convenientia, acord, Catalunya.

The convenientia played a central role in the organization of Catalan society from the beginning of the eleventh century through the end of the twelfth, but its origins are to be found earlier and farther afield. In narrative texts from before the year 1000, as well as in non-literary sources, the term convenientia possessed a wide semantic range. In some cases, it had particularly legal connotations, but it also had a variety of meanings outside of specifically legal or judicial contexts. In early medieval privates charters, especially from Bavaria, Rhaetia, and Italy, the term appeared most frequently in three contexts from among the many seen in the narrative and legislative sources: conditional grants of land, preliminary agreements, and dispute settlements. While in many cases, 
convenientia seems to refer to the agreement enshrined in a document rather than the document itself, there is ample evidence, especially in the Italian material, that the convenientia was a distinct diplomatic form.

In language and subject matter, some of the earliest Catalan convenientiae echo these early medieval acts. The near total absence of documents from the Visigothic kingdom, however, precludes a demonstration of the direct influence of earlier traditions, whether indigenous or external, on the eleventh-century Catalan scribes who first composed convenientiae. A law of the Visigothic king Egica (687-702) offers the most promising hint at institutional continuity. It refers to a convenientia in the sense of an extra-judicial settlement, precisely one of the meanings that convenientia was to take on in the future. Unfortunately, there is no evidence that this particular law was known to scribes three centuries later. As for the possibility of external influence, the evidence is similarly thin. The earliest convenientiae from Languedoc, a region from which far fewer charters have survived, are contemporaneous with the earliest examples from Catalonia. Introduction of the term into scribal vocabulary from more distant lands is possible, but we cannot point, for example, to a scribe with an Italian name associated with the first Catalan documents. Nevertheless, the fact of continuity of a Mediterranean scribal tradition, when coupled with the striking parallels between the Catalan documents and the early medieval evidence, strongly suggests some degree of influence.

In Catalonia itself, the earliest agreement with the classical form "Hec est convenientia can be dated to c.1021. The documentary context in which this form first appeared was particularly rich and, by the 1020 s, increasingly fluid. Toward the end of the tenth century, the strict adherence of scribes to formulas, such as those found in the highly influential formula-book of Ripoll, began to break down. This was perhaps connected to the disruption caused by the sack al Barcelona in 985. Records of reparatio scripturae, and more generally the poor level of documentary survival from the Barcelona region as compared to other areas, attest to the impact of this event. Whatever the precise reason for the change, scribes began to use new terms in standard types of documents. This process in especially evident in documents recording conditional grants, and it is in these that terms close to convenientia (conventio, conventus) firts became common. In some cases, a new vocabulary alone was insufficient, and scribes created new documentary types. The term convenientia itself emerged in the second decade of the eleventh century in documents recording the settlement of disputes. It is particularly in this class of documents that scribes may be seen struggling with changes in the institutions that they were called upon to record. The earliest of these signs date from the late tenth century, showing that the crisis of the old Catalonian public order began well before the minority of Berenguer Ramon I (c.1018-22) where it is usually placed.

The rise of the written oath of fidelity also signals societal trasformations. These oaths were private undertakings, rather than public collective oaths. All but one of the thirteen surviving examples datable to before 1035 involve bishops. The documents are valuable form the standpoint of the study of linguistics as 
they offer some of the earliest evidence for written Catalan. For the purposes of this study, their principal value lies in their descriptions of many of the relationships and institutions that were to become common in later convenientiae. When combined with the evidence for castle holding in the late tenth century and the precious few documents that record the terms of these arrangements, these oaths suggest that in this context, too, Catalan sociery was already undergoing a change in the late tenth century. Although the tenth-century evidence is particularly limited, it does seem that the system of vicars holding comital castles may have been much less firmly established than is usually suggested. It was out of this society in trandition, with scribes turning to new formulas, litigants turning to new modes of dispute settlement, and lords restructuring the network of castle holding, that the convenientia emerged.

The first surviving convenientia, from $c$. 1021, drew on these developments. It records an agreement between the young counts of Barcelona and Urgell and is perhaps associated with the attempt of the former, Berenguer Ramon I, to escape the tutelage of his mother, Esrmessenda. It includes conditional grants, mechanisms for the settlement of disputes, terms of castle holding, and oaths. The maturity of its vocabulary - it mentions commendation, homage, fidelity, and potestas- suggests that it should not be viewed as a true beginning, but rather as the product of forces already in effect for some time. The survival of an oath-convention pair detailing a similar agreement between the same count of Urgell and Bishop Ermengol of Urgell (1011-35) shows the close connection between these two types of documents and gives some idea of their parallel development during these years.

For the period 1020-50, the number of surviving convenientiae increases rapidly. The formula whec est convenientia» quickly became standard, while the documents in which it is found address an ever wider variety of subjects. The earliest convenientiae record conditional grants and agreements, especially intra-family settlements, treaties between great and agreements, especially intrafamily settlements, treaties between great lords, and from 1040, castle-holding arrangements. While most of these early convenientiae concern the upper levels of Catalan society - counts, bishops, viscounts, and abbots - a few do name individuals lower down on the social scale, showing that use of the document was not entirely an aristocratic phenomenon. But it was the counts of Barcelona, and specifically Ramon Berenguer I (1035-76), who made the convenientia an integral part of the Catalan social and political order.

There survive seventy-one convenientiae to which Ramon Berenguer I was a principal party, almost all as originals or contemporary copies. Catalan documentation in general does no fit into the classical schema of diplomatics, and these convenientiae in particular are not entirely homogeneous in form or content. As a group, however, they do reward a close study. The convenientia proves to be even less formal than other documentary types. Elements such as the verbal invocation, devotion formula, scribal subscription, and dating clause appear less frequently than in other comtemporary documents, or not at all. As for substance, the various convenientiae of Ramon Berenguer I fall quite neat- 
ly into five categories, categories applicable more generally to most of the Catalan convenientiae of the eleventh and twelfth centuries: commendations, oath-conventions, treaties, promises, and fiscal agreements. While the earliest of these comital documents dates from the first years of Ramon Berenguer I's reing, there is a rapid increase in output from 1058 on. This corresponds to a shift in the predominant opening formula from a balanced one ( convenientia que est facta inter...n) to an unbalanced one ("hec est convenientia quam fecit N. ad....), and a shift in the predominant types from commendations and treaties to oath-conventions. Whereas in the earlier period the convenientia had been principally a tool for making agreements, in the second half of his reign Ramon Berenguer I transformed it into an instrument of power. One might be tempted to argue that these fomal changes are more apparent than real, that they are caused by patterns of documentary survival. But the years 1057-59 were precisely those in which the count triumphed over his principal enemies. It is at that time, if any, that he would have had the opportunity to establish his power on a new footing. In adapting the convenientia to his needs, Ramon Berenguer I used the written word in a new way to define new structures of power.

Networks of castle holding were the most extensive and vital of these structures. By means of the convenientia, counts in Barcelona and elsewhere established highly articulated chains of command over castles. Agreements listed in detail the complex mutual obligations owed by the various parties. The key concept in the system was potestas, or control over a castle. Granting of potestas on demand was the mots significant obligation of a castle holder to this lord. Ramon Berenguer I was especially diligent in extracting this promise from his subordinates; other counts were less successful.

Convenientiae, those recording castle-holding agreements as well as other types, often included mechanisms to guarantee that the agreements were kept. Sometimes the guarantee was simply real (property or money), but usually it involved a combination of real and personal elements, including complex arrangements involving hostages. Convenientiae were also stabilized by means of built-in mechanisms for the resolution of disputes. These called for grace periods for emendation of wrongs and arbitration of conflicts by tribunals chosen by the litigants. The way in which these agreements functioned in the context of eleventh-century structures of power can be seen in the wealth of records, including several convenientiae, surviving from two major conflicts: one between the counts of Pallars Jussà and Pallars Sobirà, which lasted throughout the second half of the century, and the other between Ramon Berenguer I and Guillem II of Besalú in the 1050s. Convenientiae were used in cojunction with a variety of other types of documents to regulate the progress of these disputes and to bring about their ends. Both cases show, however, that despite guarantees, agreements were not necessarily kept.

Very few convenientiae have survived from the period of the conflict between Ramon Berenguer I's sons and for several years after, reflecting the disruption to the structures of power during this time. But the framework that he had 
established did persist into the twelfth century. Under the twelfth-century counts of Barcelona, the convenientia once again came to play a prominent role; over the course of that period, however, that role was transformed. Ramon Berenguer III methodically renewed the agreements entered into by his grandfather in the home counties of Barcelona, Girona, and Ausona, before embarking on a program of territorial expansion. In the newly acquired counties of Besallú and Cerdanya, he renewed agreements originally made between the counts he had replaced and their supporters. There is no evidence for similar precedents for the agreements that Ramon Berenguer III concluded north of the Pyrenees, in Languedoc and Provence, but these were comparable in form and substance to the ones in the Catalan counties. In all of these areas, the written oath predominated over the convenientia. While in areas like Cerdanya, this preference for the oath was in line with regional tradition, elsewhere it can only be explained by a shift in scribal practice or patterns of survival. The detailed contents of the oaths, however, show that at least in this case, while the form of record changed, the structures remained the same.

Under Ramon Berenguer IV, the renewal of oaths and conventions for the holding of castles continued, but so did the changes in documentation. More and more the convenientia was used for high-level treaties, while scribes turned to new language and formulas for castle-holding agreements. Ramon Berenguer IV's reign also saw an increase in collective oaths to the count, a development probably influenced by Aragonese practice. These changes are even more evident under Alfons I. Three trends are particulary significant, each reflected in the development of new types of documents that gradually replaced the convenientia. The first is the growth in the number of castles granted as fiefs; there was an acceleration in the dissolution of the long-standing distinction between the commendation of a castle and the grant in fief only of the associated lands. Related to this was the more frequent recourse to the fief de reprise for establishing control over castles. The second trend is the shift form fidelity to homage. Whereas earlier counts had received promises of fidelity in return for their commendations of castles, Alfons's grants in fief were often accompanied by documents explicitly recording the homage of the recipient. Third, Alfons increasingly granted licenses to fortify certain sites and received individuals and lands into his protection.

The differences reflected by these documentary transformations are often difficult to judge. There may have been no significant practical distinction, for example, between a commendation and a grant in fief. These developments may all be seen, however, as a new shift in the expression of comital power. Alfons's relationships with his subordinates, particularly those holding castles from him, were less frequently recorded in the form of the convenientia a form that might imply equality between the two parties. This type of document was now reserved for treaties with those outside of his immediate control, individuals with similar power, such as the kings of Castile, the counts of Toulouse, and the still independent count of Urgell. He had ample opportunity to enter into agreements with these lords in the course of his extensive military and diplo- 
matic activity north and south of the Pyrenees. This change in the count-Kings' use of the convenientia reflects an increasing distance between ruler and ruled, a distance more appropriate to the new royal rank. The Liber feudorum maior, a collection of older agreements, but one intended as a living document, is a further expression of this new conception of comital and royal strength.

From its first appearance in the region, the convenientia was not solely a tool of the counts. It also served to articulate social, political, and economic structures among other segments of Catalan society. The most significant of these, and the most neglected by earlier scholarship, were the structures of episcopal military lordship. Similar patterns and chronologies of development are evident in each of the four principal dioceses (Barcelona, Urgell, Girona and $\mathrm{Vic}$ ), although there are notable regional differences. The dioceses bordering on the frontier with Islam each acquired castles at the close of the tenth century as part of comital programs of defense and resettlement. Changes in the documentation of castle-holding arrangements parallel those seen in the comital evidence, with a sharp rise in the use of oaths and conventions from the mid-eleventh century. In each of the dioceses, this restructuring was associated with the long mid-century tenure of a powerful lord bishop: Guilabert (1035-62) in Barcelona, Berenguer Guifré (1050-93) in Girona, Guillem de Balsareny (1046-75) in Vic, and Guillem Guifré (1041-75) in Urgell. In the twelfth century, though these structures persisted, the dioceses were increasingly involved in dispures concerning their castles. Here the differences among the dioceses become more apparent. In Barcelona and Girona, these conflicts tended to concern the castles as sources of revenue; at Vic and especially at Urgell, political and geographical circumstances led the bishops to maintain a stronger interest in the castles as sources of military service. On the whole, the organization, articulation, and expression of episcopal power mirrored closely that of comital power for much of the perior in question.

The lower levels of both the comital and episcopal castle-holding networks consisted primarily of agreements between members of the lay aristocracy. The chronology, form, and substance of the surviving documentation detailing these ageements demonstrates the profound influence of Ramon Berenguer I in making the convenientia an important element of Catalan social and policical structure. In fact, the convenientia enjoyed more consistent and widespread use at these lower levels: while the comital documentation was changing to express a new conception of power in the twelfth century, the lay aristocracy continued to enter into convenientiae. Structures established in the 1060 s and 70 s can be shown to have persisted wiith little change for over a century. Most of these agreements were not simple engagements with a castlà, the lowest member of the hierarchy of control over castles; they were usually complex arrangements between individuals at the middle levels of the chains of command. It is in the proliferation of these agreements - agreements establishing relationships of power over castles, but also economic and political ties and structures of alliance - that the convenientia may be seen most clearly embodying social order. Monasteries, too, played a role in these net- 
works, although here the sources are much less informative. At the few foundations for which sufficient evidence survives to permit generalization (Santa Maria de Gerri, Sant Cugat del Vallès, Sant Pere d'Äger), monastic interest in castles was almost entirely economic; unlike epicopal power, any military strength enjoyed by abbots and priors was mediated through secular lords.

While the majority of the surviving convenientiae record links in these networks of castle holding, the forms was uses throughout Catalonia for a broader range of agreements. In many ways, these documents show the strongest diplomatic ties to the early medieval records and to the context in which the convenientiat emerged in Catalonia. Alongside a number of other forms, convenientiae defined many of the agreements by which the rural economy of Catalonia was constructed. Parties turned to these documents to establish agrarian contracts, leases, grants in fief, and a variety of other conditional tenurial arrangements. Some of the earliest convenientiae recorded intra-family arrangements, and this continued to be a common application of the form throghout the period. Families at all social levels arranged their affairs by means of these documents especially matters of inheritance and tutorship. The comvenientia served not only for agreements between lineages, but also within lineages. These family agreements only rarely concerned oaths, conventions, and castle holding. Finally, convenientiae also continued to play an important role - again, alongside other documentary forms - in the less formal structures of dispute settlement that replaced the old comital placitum for much of the eleventh an twelfth centuries.

The compilation of the Liber feudorum maior signaled the demise of the convenientia, which had been transformed at the Barcelonese court over the course of the twelfth century, and especially after 1150 . The lay aristocracy continued to use convenientiae consistently through the 1170 s, but the numbers of these documents declined slowly thereafter. Ecclesiastical seribal practice was perhaps the most conservative, although even in episcopal and monastic documentation a turn away from the convenientia is noticeable in the last decades of the century. But demise did not mean disappearance. Examples of the convenientia, even in its classical form, can be found from 1196, the year of the death of Alfons I, and after.

The chancery of Pere I continued to use the formula ahec est convenientian on occasion, as in a treaty between the count-king and Ermengol VIII of Urgell in $1200^{1}$. His scribes referred to several other agreements as convenientiae without using this formula ${ }^{2}$. Survivals may be cited from outside the court; as well. In

1. OM 11: 1903 Joaquim MiRET i SANS, Imestigación bistórica sobre el vizcondado de Castellbó (Barcelona, 1900), ap. 17 (p.378-80)\}; another copy at OM, leg. 683, doc. 5.

2. PEI 188 \{DI 8:35\} (a. 1204): «supradictam convenientiam attendamuss, PEI 298 [DI 8:38\} (a. 1208): whanc convenientiam vel compositionems. 
1206, Pere de Claramunt commended by means of a convenientia a fortification to Guillem de Montbui in return for a promise of aid and fidelity ${ }^{3}$. In 1218 , Bernat, prior of Santa Maria de Mur, and Ramon deTongui concluded a convenientia, as did Guillem, prior of d'Estany, and Bernat de Casseres in $1228^{4}$.

Renewals of earlier documents encouraged the persitence of the form. When an episcopal scribe drew up a convenientia between Pere, bishop of Barcelona, an Guerau de Palamors in 1211 concerning the castle of Montmell, he could look back on a series of convenientiae related to that castle 5 . Similary, the convenientia by which Guillem, bishop of Vic, commended the castle of Artés to Guillem de Guardia in 1199 had clear precedents ${ }^{6}$. This latter document survives in trasncriptions of 1227 and 1281, highlighting the fact that the constant recopying of documents also served to keep the form in circulation. The existence and use of cartularies, many compiled in precisely these years when the convenientia was dying out, would have had a similar effect.

Even when the form itself was not used, however, documents referred back to earlier convenientiae, perpetuating the use of the term for certain types of agreements. Thus the agreement in 1210 between Elvira de Lara and Pere I concernig the proposed marriage of their respective children Aurembiaix and Pere (the future Jaume I) included a clause preserving the validity of the convenientiae agreed between Ermengol VIII and Guillem, viscount of Cardona, a few years earlier ${ }^{7}$. In 1226, Roger Bernat, count of Foix, and his wife Ermessenda swore to the bishop of Urgell (1199-1203) that they would observe the sconvenientiae agreed between lord Bernat de Vilamur, the late bishop of Urgell, and... Arnau de Castellbò, which agreements they had studied and fully understood ${ }^{8}$. In 1248, Ramon de Vernet claimed rights in the castle of Sant Oliva from the monastery of Sant Cugat on the basis of a «convenientia that was made between Pere de Sant Oliva, and Pere de Banyeres and Bernat de Banyeres, his brother, on 8 January $1174 n^{9}$.

The diffusion of the Usatges in the late twelfth and thirteenth centuries also played a role in maintaining the convenientid in scribal consciousness ${ }^{10}$. As noted earlier, the term contenientia appears only once in the text of the code, in reference to an association of knights; an agreement between lord and

3. Dòdena 59.

4. BC, MS. 150, no. 151 (f. 109v-110r); MEV, MS. 283, no. 127.3 (f. 72r-v).

5. LA 4:416 \{Mas 2441\}. See above, c. 5, n. 34 f.

6. AME 10:6. Cf. AME 10:2; ACB 1-5-445.

7. PEI 378 \{Ferran VALLS i TABERNER, «Els origens dels comtats de Pallars i Ribagorças, Estudis Universitaris Catalans, 9 (1915-16), 1-101 at 66-68 = "Els comtars de Pallars i Ribagorça a partir del segle XIs, in Obras selectas, vol. 4, Estudios de historia medieval (Madrid-Barcelona, 1961), 125-205 at 160-63\}. See AURELL, Les noces du conte, 357-58.

8. MIRET i SANS, Investigación histórica, ap. 18 (p. 380-82).

9. CSC 1387. I have not been able to locate the earlier document.

10. See, generallly, Josep M. PONS i GURI, *Corpus iuris", in Documents jurldics, 111-34 at 120-24; The Usatges of Barcelona: The Fundamental Law of Catalonia, trans. Doland J. KaGAY (Philadelphia, 1995), 44-46. 
man, however, is referred to in the text as a conventio, which in the earliest Catalan version is rendered convinenca. This is a slim basis for linguistic influence, but the detailed description in the Usatges of the institutional framework in which the convenientia flourished certainly helped to perpetuate an awareness of it. The same may be said of the influential explication of these institutions in the Commemomacions of Pere Albert ${ }^{11}$. Ironically, the code, which as argued above had only limited impact for much of the twelfth century, enjoyed greater success after the convenientia began to decline. On the one hand, the code as a whole or individual usatges were imposed on municipalities and territories acquired by the count-kings. On the other, from Alfons I's first attempts to create an administrative peace at Fondarella in 1173, the Usatges became a focal point of the conflicts between the count-kings and the barons, developing quickly into a Catalonian national law. This status was confirmed by decrees of Jaume I in 1243,1251 , and 1276 , establishing the Usatges as the all but exclusive norm for the functioning of comital-royal courts.

Despite these elements of continuity, the Catalan social order began in the late twelfth century to move away from the organization in which the convenientia had played a prominent role ${ }^{12}$. Networks of individual agreements were replaced by differents types of power structures. Towns grew not only in size, but in political importance. The small, powerful patrician group that arose in Barcelona berween 1140 and 1220 had a significant impact on comital policy ${ }^{13}$. The townsmen of Vic failed to establish a consular organization in the 1180 s, but Pere I granted this right freely in the next decade ${ }^{14}$. Towns sent representatives to assemblies from the beginning of the reign of Jaume I. The efforts of Alfons I to establish a territorial government for Catalonia, beginning with the Peace of Fondarella in 1173 , sparked a series of constitutional developments that would lead to the formation of the Corts in the course of the thirteenth century. Already in 1188-92, a baronial opposition had developed to protest these changes; the barons managed then to disrupt partially Alfons's program, but their success was only temporary. These changes institutionalized power in ways fundamentally different from the eleventh - and twelfth-century norms. The history of the thirteenth century is best studied not by an examination of networks of individual agreements, but of the activity of various interests: municipal, mercantile, royal, baronial, clerical.

11. Usatges de Barcelona $i$ Commemoracions de Pere Albert, ed. Josep Rovira i Ermengol, Els nostres clàssics, Col-lecció A, 43-44 (Barcelona, 1933), Commemoracions, c. 6, 15 (p. 145, 152-54); sles covinences!, acovinençav. See Tomàs de MONTAGUT, "La recepeión del derecho feudal común en Cataluña (Notas para su estudio)s, in Manuel SANCHEz Martinez, ed. Estudios sobre renta, fiscalidad y finanzas en la Cataluña bajomedieval, Anuario de estudios medievales, Anejo 27 (Barcelona, 1993), 153-75 at 160.

12. See, generally, Thomas N. Bisson, The Medieval Croun of Aragon: A Stsort History (Oxford, $1986), 40-56,72-82$.

13. BensCH, Barcelona and its Rulers, esp. 170-233.

14. Paul FrFEDMaN, «An Unsuccessful Attempt at Urban Organizarion in Medieval Catalonia», Speculum , 54 (1979), 479-91. 
These large-scale trends made the convenientia obsolete, but it is possible to point to more specific causes of its demise. The most significant development was the introduction of Roman law and its impact on scribal culture ${ }^{15}$. It is impossible to assign a single date to the areception* of Roman legal learning in Catalonia. While earlier documents echo texts and ideas of the ius commune, the Usatges themselves, in their compilation from $c .1150$, are perhaps the first sign of significant influence, with their Romanist conception of princely power. Unquestionable reference appear under Alfons I, in the 1170 s, although many of the earliest are rejections of the new principles, rather than applications of them. A manuscript of the Digest was in the possession of the canons of the cathedral of Barcelona by 1188 , as was the entire Corpus by the mid-1190s. Individual usatges datable to the reigns of Alfons I and Pere I draw on Roman law, as do municipal custumals such as the one for Lleida of 1228. Despite popular and official objections to the new legal currents - scen, for example, in Jaume I's prohibitions - the opponents were fighting a losing battle.

The key factor was not so much the Roman law itself, but the rebirth of the public notariate and the Italianate practices that accompanied it ${ }^{16}$. In the treaty of April 1176 between Alfons I and Ramon of Toulouse, Alfons's scribe, Bernat de Caldes, called himself a tabellio and the document an instrumentum; this is only most striking evidence of a change, not the first ${ }^{17}$. The bishop of Vic had appointed a scriptor publicus for the town by 1155 ; in 1194, the canon Andreas was appointed escriptor omnium cartarum Vicensis ville et tocius parrochie Sancti Petrim for life, and he subscribed as a escriptor publicus» thereafter $^{18}$. The levita Ermengol served as publicus scriptor of Girona perhaps as early as 1161 , and certainly by $1182^{19}$. Alfons I established public notaries at Vilafranca del Penedès in 1188, Maresa in 1191, and Montblanch in 119420. Pere I did the same for the monastery of Santes Creus in 1211; Sant Cugat could claim its own from $1218^{21}$. These notaries quickly imported a documentary typology in which the convenientia had no place.

15. For what follows, see Pons i Guri, «Corpus iuris», esp. 118-21; Thomas N. Blsson, «Ramon de Caldes (c.1135-1199): Dean of Barcelona and King's Ministern, in Medieval France, $187-98$ at $198 \mathrm{n} 70$.

16. José Bovo, Historia del derecho notarial espanioh, 1 vol. in 2 parts to date. Ars notariae hispanica I (Madrid, 1979-), 1.1:118-22, 292-329; 1.2:128-39; Félix DURAN CAÑameras, "Notas para la historia del notariado cacalán", Estudios históricos y documentos de los archivos de protocolos, 3 (1955), 71-207 at 73-87; PONs i GURI, "Corpus iuris\%, 118.

17. LFM 899; see above, Table 4.3a.

18. ACV 6/i/55; BONO, Historia, 1.1:316n53.

19. CCM 306, 345 .

20. BONO, Historid, 1.1:318, 1.2:129; DURAN, «Notas», 78-79. CPF 188 (confirmation of notariate at Vilafranca in 1191): satque omne aliud ius et rationen quod habeat eadem ecciesia ubique locorum ibidem laudamus et confirmamus et nominatim scribaniam eiusdem ville quam ei iam dudum assignavimuso:

21. Antoni M. Aragó, „L'escrivania pública de Santes Creus a l'época post-fundacionals, in I Col.loqui d'bistòria del monaquisme català, 2 vols. (Santes Creus, 1967-69), 2:15-25. 
The appearance and dissappearance of the convenientia are linked to changes in the structures of Catalan society. Only during the eleventh and twelfth centuries, when these structures were defined primarily by networks of individual agreements, could the convenientia flourish. Possibility is not the same as necessity, however, and the question remains of why the participants in these agreements put them in a written form. Convenientiae might serve as proof in the course of a later dispute, but proof could cut both ways: the loss of a written record of an agreement could lead to its dissolution. Ramon Berenguer III learned this lesson when he had to absolve the guardians of the castle of Arraona from their oath and homage to him because he was unable to find the relevant scripturae 22 . If such scripturae had never existed, it might have been easier for the count to prevail. The reason for the rise of these agreements in a written form are neither simple nor self-evident.

Appeals to a shift from oral to written culture cannot work in this context. While the argument may be made for a transition ufrom memory to written record, beginning in the eleventh century in other regions of Europe, it is bound to fail for Catalonia ${ }^{23}$. The five thousand tenth-century documents that have survived in the archives are the surest indication that this was a sociery profoundly familiar with the written word. This familiarity was required by the $V$ isigothic legal culture that still dominated the society. References to documents appear throughout the Liber iudiciorum, in titles concerning judicial procedures, testamentary practice, and transaction of many types. Book II, Title 5 (De scripturis valituris et infirmandis ac defunctorum voluntatibus conscribendis) and various titles of Book V (De transactionibus) were constantly cited in Catalan documents of practice 24 . The breakdown of that culture in the late tenth and early eleventh century may have led to a loss of respect for written proof in the context of the old legal procedures, but it did little to alter the status of the written word in the society as a whole. In 1064, the scribe of a charter of sale could still write: "The law decrees that documents should be present in all matters ${ }^{25}$.

Another attempt to describe a transformation in literacy in the eleventh century argues for a new interaction of the oral and the written: "oral discourse effectively began to function within a universe of communications governed by $\operatorname{texts}^{26}$. This argument, too, rests on the notion of a fundamentally oral tenth

22. RBIII 174 \{Bisson, «Feudalisms, ap. 1 (p. 173)\}. See above, c. 4, n. 59.

23. M/ichael) T. CLANCHY, From Memory to Written Record: England 1066-1307 (Oxford, 1993, \{Cambridge, Mass., 1979\}).

24. See works cited above, c. 1, n.160. One example among many -DACU 666 (a. 1054): *Et supradicti heredes fecerunt inter eos pacta vel placita sicut est in libro . $\mathrm{ii}^{\circ}$. chapitulo ii ${ }^{\circ}$. de pactis vel placitis conscribendisw.

25. ACV 6/285 \{cit. Bonnassie, La Catalogne, 1:22n19\}. Cf. Michel Zimmermann, „Protocoles et préambules dans les documents catalans du Xe au XIIe siècle: Évolution diplomatique et signification spirituelles, Melanges de la Casa de Velázquez, 10 (1974), 41-76 and 11 (1975), 51-79, at 11 (1975), 52.

26. Brian STOCK. The Implications of Literacy: Written Language and Models of Interpretation in the Eleventh Centuries (Princeton, 1983), 3. 
century, a description that does not apply to Catalonia. Convenientiae and associated documents do provide evidence for an interdependence of oral and written modes, however. This is abundantly clear in some of the earliest documentation, especially the convenientia between the bishop and count of Urgell and the accompanying oath. The convenientia records the content of the oath to be sworn, while the second document records the oath to be sworn, while the second document records the oath itself in the first person. The presence of lengthy passages in the vernacular (e.g., "si tu recebr.o vols o tal consell te.n fare que tur recebras per tal vollentadn) suggest strongly that the scribes was recordind verbatim an oral ritual. In later documents, though, vernacular passages became limited to certain relatively brief stock phrases. A blank oath from the reign of Ramon Berenguer III, almost entirely in Latin and with a space left for the name of the juror, attests to the fact the that the oath quickly became as much a written as an oral $\mathrm{act}^{27}$. But while this model of interaction of oral and written modes helps to explain the development of those convenientiae that were accompanied by oaths, and perhaps by other rituals such as homage, it does little to explain the rise of all types of these written agreements in this period.

Nor can their appearance be explained by a growth in "legal illiteracy». This model has been applied to the rise of new types of instruments in the fourth and fifth centuries, instruments that were unnecessary in the classical Roman law: "where the law was no longer understood, it had to be spelled out, illustrated and explained ${ }^{28}$ n. The Visigothic legal order did not collapse because of a loss of legal learning; an increasingly professional corps of judges served through the first half of the eleventh century. The Barcelonese judges Auruç, Ervig Mard, Ponç Bonfill Marc, and Bonhom stand out for their activity in the first two decades of the century, the last named as the compiler of the Liber iudicum popularis ${ }^{29}$. Ramon d'Abadal, as noted above, credited the judge Guifré with the creation of the episcopal castle-holding scheme at Vic in the 1020 s, enshrined in new types of documents that foreshadowed the convenientia ${ }^{30}$. The decline of the judicial corps followed and was the result of, rather than a cause of, the decline of the comital placitum. The new form of the convenientiae developed because of the inadequacy of the old forms to meet the needs of a society undergoing structural transformations, not because people lost their ability to understand these old forms.

27. RBIII extra. 2401 (presently missing) (ed.: Josep TrENCHS, „La escribanía de Ramón Berenguer III (1097-1131). Datos para su estudion, Saitabi, 20 (1981), 11-36 at 36; trans.: Usatges, trans. Kagay, 120]. See ZIMMERMANN, "Les serments», 145-148.

28. STOCK, Implications of Literacy, $42-49$, quote at 44.

29. BONNASsIE, La Catalogne, 1:187-92; Ferran VALLS I TABERNER; „El Liber iudicum popularis de Homobonus de Barcelona", Anuario de historia del derecho españoh, 2 (1925), 200212 \{Obras selectas, vol. 2, Estudios Histórico-juridicos (Madrid-Barcelona, 1954), 235-46\}.

30. Above, c. 5, n. 100. 
The rise of the written agreement in eleventh-century Catalonia is linked to changes in literacy, but to see this the convenientia must be viewed as an example of a new function for the written word, not simply as a new form of the written word. Ourliac suggested that an essential element of the convenientia was "the insertion into the contract of an uncertain limit, that is to say a time-factor ("facteur temps") ${ }^{31}$. This factor was not only essential; it was novel. The documentary types most common in Catalonia before the year 1000 - charters of sale, donation, and exchange - were records of complete transactions, as were most of the records of judgment. Testaments often contained conditions, but these were usually tied to specific acts or events: burial in a certain location, purchase of a liturgical item, the remarriage of a widow, the return of a relative form captivity ${ }^{32}$. Pledges were conditional agreements, too, but these had definite limits; when the agreed term was reached, the pledge was redeemed or forfeited, and the document became a dead letter. The convenientia, however, imposed no limits. It described relationships that were meant to persist in time. It was a blueprint for the future rather than a record of the past. It was precisely because of this prospective character that the convenientia was able to create lasting structures.

There are other indications that in eleventh and twelfth-century Catalonia, people began to identify new functions for the written word, functions that went beyond recording completed or limited transactions. The earliest examples of agrarian contracts in Catalonia date to the mid-tenth century, but they become common only in the course of the eleventh. Clauses in these agreements that limited the transactions to one or two lifetimes gave way to language that implied perpetuity ${ }^{33}$. The short-term pledge developed into an agreement for the extended exploitation of lands; the earliest such eopen-ended pledge" for Barcelona dates from $1080^{34}$. Parties entered into speculative agreements, granting or deciding the terms of tenure for lands not yet acquired ${ }^{35}$. Simple inventories of lands became inventories of rights in lands and their inhabitants, reflecting both a new interest in fiscal management and a documentary development from simple record to tool of administration ${ }^{36}$.

31. OURLIAC, "La "convenientia" $", 248$.

32. STAC, p. 128-30.

33. See above, c. 6, n. 124.

34. BENsch, Barcelona and its Rulers, 113-14.

35. See J (oseph\} DELAVILIE Le RourX, Cartulaire général de l'Ordre des Hospitaliers de Stint-Jean de ferusalem, 4 vols. (Paris, 1894-1906), no. 426 (1:295-96); Jaime CARUANA, wltinerario de Alfonso II de Aragónn, Esrudios de Edad Media de la Corona de Aragón, 7 (1962), 73. 298 at note 249 ; above, c. $3, \mathrm{nn} .80,120 ;$ c. 4 , n. 103 ; c. $5, \mathrm{n} .170$; and the comments of Fredric L. CHEYETTE, eThe 'Sale' of Carcassonne to the Counts of Barcelona (1067-1070) and the Rise of the Trencavelsw, Speculum, 63 (1988), 826-64 at 863-64.

36. Part of this evolution be seen on a single parchment from Vilamajor: Anscari M. MUNDO, eDomains and Righes of Sant Pere de Vilamajor (Catalonia): A Polyptych of c. 950 and c. 1060w, Speculum 49 (1974), 238-57. See also FA; Pere Bentro I MonCLUS, *Hoc est breve: L'emergència del costum i els origens de la pràctiva de capbrevación, in SANCHEZ MARTINEZ, ed., Estudios sobre renta, fiscalidad y finanzas (above, n. 11), 3-27. 
The shift in literacy was not one from memory to written record, but from memory to imagination, from the use of writing to reconstruct the past to the use of writing to construct the future. Was this part of a rethinking of time irself? A reassessment following the destruction of Barcelona in 985, or even the relatively uneventful passing of the millennium $(s)^{37}$ ? The answer will be found with closer study of the full range of charter evidence from this region. But the acceptance of new uses of literacy clearly allowed for a functional change in the documentation just when trasformations in Catalan sociery promoted the importance of individual agreements. These changes explain the appearance of the convenientia in Catalonia in the eleventh century. This written agreement permitted and indeed facilitated the creation of structures for Catalan society, structures meant to last, in the words of the oath, de ista ora in antea.

37. Michael ZimmermanN, aLa prise de Barcelone par Al-Mansûr et la naissance de l'historiographie catalanes, Annales de Bretagne et des pays de IOUest, $87(1980)\}=L$ 'historiographie en Occident du ve au Xve siècle, Actes du congrès de la Société des historiens médiévistes de l'enseignement supérieur, Tours, 10-12 juin 1977], 191-218. Richard LANDES offers a spirited rehabilitation of the relevance of the millenium in Relics, Apocalypse, and the Deceits of Hisrory: Ademar of Chabannes, 989-1034, Harvard Historical Studies, 117 (Cambridge, Mass., 1995), esp. 285-327. 